\title{
Innovation policies for advanced biorefinery development: key considerations and lessons from Sweden
}

Hans Hellsmark, Chalmers University of Technology, Gothenburg, Sweden Patrik Söderholm, Luleå University of Technology, Sweden

Received June 22, 2016; revised September 30, 2016; accepted October 4, 2016 View online at Wiley Online Library (wileyonlinelibrary.com); DOI: 10.1002/bbb.1732; Biofuels, Bioprod. Bioref. (2016)

Abstract: This paper provides an innovation systems perspective on the combination of policy instruments that will be required to stimulate technological development in the advanced biorefinery field. We first consult the established innovation policy literature, and provide a general framework that can be used to identify the type of policy instruments needed to develop new sustainable technology. In a second step, we illustrate how these general principles can be applied in the context of future biorefineries based on either the thermochemical or biochemical conversion of lignocellulosic biomass feedstocks. We draw heavily on the experiences of biorefinery development in Sweden. A central conclusion is that in Sweden, and elsewhere, there are few niche markets for advanced biorefineries and a lack of long-term policy instruments for the more established renewable fuels. For this reason, there is a need for innovation policy instruments that create markets for renewable fuels and green chemicals, thus supporting technology development during a niche market phase and allowing for the first commercial-scale plants to be built. The aim of such a policy would be to stimulate learning, form value chains, and experiment with various design options on a larger scale; this complements the use of technology-neutral policy instruments such as carbon pricing, which primarily promotes the diffusion of mature technologies. The policy instruments that are candidates for the niche market phase include, for example, public procurement and various types of price guarantees. (C) 2016 Society of Chemical Industry and John Wiley \& Sons, Ltd

Keywords: policy mix; innovation policy; industrial capacity; biorefineries; biofuels. 


\section{Combating climate change and gaining competitiveness}

$\mathrm{n}$ order to attain the global 1.5-degree target, the Western world needs to achieve virtually zero greenhouse gas (GHG) emissions by 2050 - i.e., less than 35 years from now. ${ }^{1}$ From a global technological development perspective, 35 years represent the blink of an eye. It typically takes several decades for new technology to be developed and diffused in global markets. ${ }^{2,3}$ This implies that most lowcarbon technologies available today must be diffused in parallel with the development and commercialization of new technologies in virtually all sectors. Such a transition toward a zero-carbon society presents great challenges, but it also offers an opportunity for innovation and for strengthening the long-term competitiveness of various industrial sectors.

In these respects, a transition toward a bio-economy is increasingly emphasized by international actors, such as the International Energy Agency (IEA), the Organisation for Economic Co-operation and Development (OECD), etc., as well as by national governments. ${ }^{4-6}$ For the industry and transport sectors, managing this transition largely hinges on biorefinery development. Based on a flexible intake of forest residues and/or other lignocellulosic raw materials, biorefineries permit production of large quantities of bulk products such as biofuels along with other high-value products such as specialty chemicals. In this paper, we focus solely on the development of so-called advanced biorefineries. These are based on either of two technological platforms: thermochemical or biochemical conversion of lignocellulosic biomass feedstocks. ${ }^{* 7,8}$ If deployed on a commercial scale, advanced biorefineries hold the potential for industrial renewal of mature process industries while, at the same time, create opportunities for new businesses through the creation of innovative value chains and products (e.g. biofuels, green chemicals).

Most advanced biorefinery technologies are not yet commercial and their future development depends on investment in thermochemical and biochemical conversion of biomass. ${ }^{9}$ However, investments in either of these two platform technologies are highly capital intensive and imply significant risks. This makes the development contingent on public policy support to stimulate knowledge generation and progress along the learning curve. At the same time, due to a combination of economic challenges

${ }^{*}$ This focus on advanced biorefineries, i.e., the integration and utilization of biochemical and thermochemical conversion processes, therefore excludes, for instance, hydrogenated vegetable oils (HVO) and the production of first-generation fuels in combined processing plants, unless this is combined with the above-mentioned platform technologies for processing lignocellulosic feedstocks. and increasingly uncertain public policies in both Europe and North America, the development of advanced biorefineries has progressed slower than anticipated. ${ }^{10,11}$ Many plans for large-scale plants have been abandoned and only a limited number of demonstration and semi-commercial scale plants have been constructed. ${ }^{11}$ This therefore begs the question of what future policies - and combination of policies - need to be implemented to promote the development and commercialization of advanced biorefineries.

This paper has two aims. The first is to provide a general framework that can be used to identify the types of innovation policy instruments required to develop new sustainable and zero-carbon technology. The second aim is to illustrate how these general principles can be applied in practice to realize the development of advanced biorefineries. Specifically, in a first step we derive general insights from the established innovation policy literature, and in a second step we analyze the role of innovation policy mixes in the empirical context of Swedish biorefinery development. The latter part builds on our own analysis of weaknesses in the Swedish biorefinery innovation system. ${ }^{12}$ Specific policy instrument options are also briefly discussed and evaluated.

In order to achieve a significant global penetration of biofuels and green chemicals, certain regions and countries will be required to take the lead by actively promoting both technological development and the subsequent diffusion of new technologies. Sweden has expressed such ambitions. In a speech at the UN Sustainability Summit, 26 September 2015, the Swedish Prime Minister Stefan Löfven stated: 'My goal is for Sweden to be among the first fossil-free welfare nations, and I want Swedish companies to develop the climate-smart innovations that the world is asking for.' ${ }^{\prime 3}$ The transition to a bio-economy is an essential component of this political ambition.

In Sweden, bioenergy already accounts for $37 \%$ of total primary energy supply, and more than 175000 people are employed in forest-related industries. ${ }^{14}$ The country also already hosts biomass-based refineries that produce fuels in combination with other products, but these facilities are largely based on mature technologies. ${ }^{\dagger}$ In order to further stimulate this development, Swedish industry, government, research institutes, and academia have partnered in developing and demonstrating more advanced biorefinery

\footnotetext{
${ }^{\dagger}$ The existing biomass-based refineries in Sweden focus on: (i) hydro-treatment of vegetable oils developed and operated by the oil company Preem in collaboration with the forest-based company Sunpine that extracts tall oil for diesel production; (ii) agrarian-based fuel technologies developed and operated by the chemical company Perstorp and the Swedish farmers' cooperative Lantmännen; as well as (iii) forest-based resources combined with the production of dissolving cellulose at the mill, developed and operated by Domsjö Fabriker.
} 
concepts in terms of which types of biomass feedstocks that can be processed.

A number of production processes have been demonstrated and these include: (i) biochemical conversion of forest-based resources for the production of ethanol; (ii) thermochemical conversion of black liquor through entrained flow gasification for the production of dimethyl ether (DME) and methanol; (iii) thermochemical conversion of forest-based resources through indirect gasification for the production of methane; (iv) the substitution away from coal and oil through torrefaction (drying) and pyrolysis of biomass; and (v) extraction of lignin from black liquor produced in a paper and pulp mill for further refinement into fuel or other high-value applications. ${ }^{12,15}$

These demonstrations and technical concepts have resulted in several working technology trajectories that have been tested in practice, and a wide range of new actor networks and alliances across the respective value chains have been formed. Many of the new trajectories could be integrated with existing industrial structures in, for example, the petrochemical and oil industries, the district heating sector, the pulp and paper industry, existing biorefineries, and biofuel plants. In this way, future advanced biorefineries could serve as platforms for an industrial revitalization of mature industries, and create prerequisites for new businesses and sustained industrial competitiveness in Sweden.

Nevertheless, in spite of the progress made and the farreaching policy ambitions, no biorefineries based on these technical concepts have been built on a commercial scale. There is, therefore, a risk that large-scale industrialization of advanced biorefineries will not take place. The hitherto large $R \& D$ investments may, therefore, not generate any returns and the commercialization of the state-funded knowledge generation may instead take place in other countries or regions.

The obstacles to commercializing advanced biorefinery concepts in Sweden - and elsewhere - should, we argue, primarily be attributed to a lack of adequate innovation policies and much less to technical failures and risks. In this paper, we argue that a successful innovation policy needs to be based on a systems perspective on innovation, taking its point of departure in the critical feedback mechanisms between knowledge generation and market development. These mechanisms are necessary so that new technology trajectories with high long-term potential will be able to mature and compete with established alternatives in the market. This implies in turn that innovation policy must be aimed at stimulating firms to build networks, experiment, and learn how the new technology could work on commercial terms, while at the same time eliminating institutional barriers (i.e., legal rules, norms, etc.) to such learning. Thus, a systems-oriented innovation policy does not only promote $\mathrm{R} \& \mathrm{D}$, it also has a strong focus on learning and associated gradual market formation through deployment policies and the creation of socalled niche markets.

An in-depth understanding of how policy can promote the development of advanced biorefineries, drawing on important practical lessons from the Swedish case, should be essential for also giving other countries with trailblazer ambitions the insights necessary to harness such a development. Adequate innovation policy instruments for stimulating the development of advanced biorefineries are lacking also in other key countries, both in Europe and in North America. ${ }^{10}$ For this reason, the key arguments in this paper should be of interest well beyond the Swedish case; they will assist policymakers and other actors internationally to capitalize on existing strengths and to formulate efficient policies for the further commercialization of advanced biorefineries.

The paper proceeds as follows. First, we describe and discuss the main elements of an innovation policy mix based on a systems perspective, and why such a perspective is essential. This is followed by a description of the main system weaknesses that obstruct the realization of future biorefineries. The focus is on the situation in Sweden building on our own analyses of key system weaknesses, although studies show that similar weaknesses exist also in the biorefinery innovation systems of other countries. ${ }^{10}$ The paper proceeds with an analysis aiming at identifying an efficient combination of policy instruments that can address the weaknesses in the innovation systems for advanced biorefineries in Sweden and elsewhere. Finally, we conclude the paper.

\section{Innovation policy from a systems perspective}

At least since the pioneering works of Joseph Schumpeter, innovations in the form of novel products and services have been identified as keys for the creation of new firms and industries, including the revitalization of existing industrial structures. ${ }^{16}$ Schumpeter introduced an analytical distinction between invention and innovation, where invention represents an intellectual process that can lead to a patent, new concepts, or the like, while innovation involves the deployment of new knowledge, technology, products, or services in the market. In the remainder of 
this section we discuss the prerequisites for successful innovation and the role of policy in stimulating this.

\section{The importance of iterative learning processes}

A proper understanding of innovation processes and how these can be reinforced is required to stimulate innovation and promote economic development. The dominant innovation model has been the linear model according to which investments in basic research eventually result in the development, innovation, and diffusion of new products (so-called technology push). Sometimes the connections are believed to be reversed, thus building on the notion that innovation is spurred only if new markets can be established (so-called demand-pull). ${ }^{17}$ Even though this linear innovation model has been declared dead by innovation scholars since the mid-1980s, ${ }^{18}$ it still tends to dominate the logics in some policy circles. For this reason, it is important to present clear alternatives.

The more recent literature emphasizes that the relationships between research, development, and diffusion of new innovations are far more complex than suggested by the linear model. An effective innovation policy must proceed from the feedback between each stage of the innovation and diffusion processes. We also know that the prerequisites for innovation may differ significantly from one technological field to another (e.g. as a result of institutional barriers). Figure 1 illustrates the main differences between the linear model and what we refer to as the systems-oriented innovation model. In addition to its emphasis on the role of iterative learning processes, the latter model also recognizes the importance of market formation, i.e., the process involving taking the step from early demonstration to mass markets.

There are key feedback phases between all stages of the innovation process, not least between the market formation, demonstration, and $R \& D$ stages. This feedback generates learning where customers, technology suppliers, and researchers contribute to the development in various ways. Two specific learning processes often highlighted in the literature are learning-by-doing and learning-by-using. The former refers to the learning that occurs in production as it is scaled up; larger volumes entail larger investments in increasingly efficient processes and the firm can exploit economies of scale. Learning-by-doing also refers to any
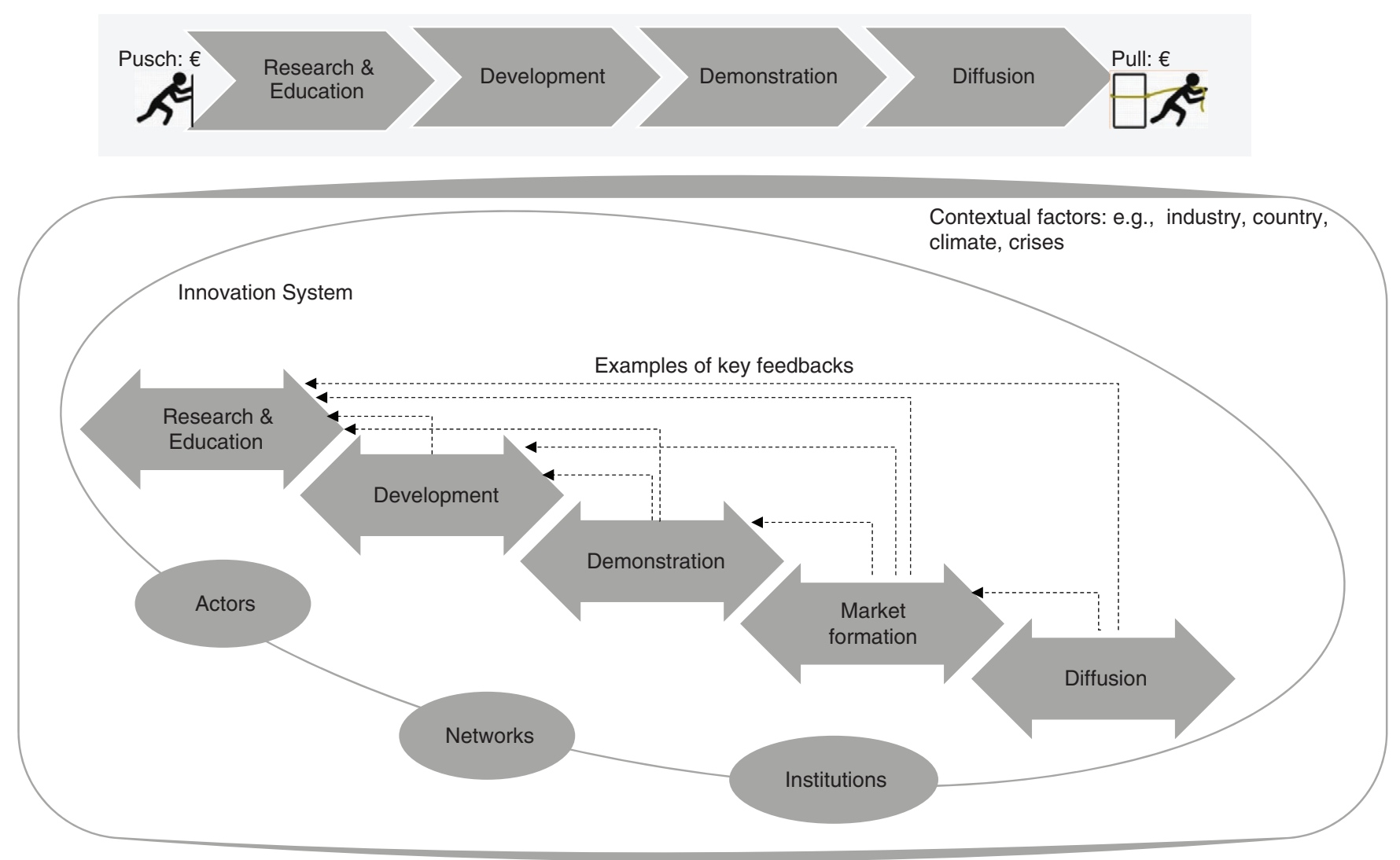

Figure 1: The difference between linear and systems-oriented innovation models. Source: IEA (2015). 
tacit knowledge acquired during manufacturing. In contrast, learning-by-using refers to the learning that occurs in connection with the use of the products, i.e., when customers give feedback to suppliers and devise new ways to use or integrate the products in their daily lives and/or in existing production processes. ${ }^{19-21}$

These learning processes make possible improvements in the price/performance ratio for new innovations and improve the conditions for further diffusion as new markets and applications are opened up. Markets do not exist from the outset, but are instead created in the interactions among key actors. As new markets are formed, companies become more interested in participating in the technological development process. This also creates opportunities for reforming existing laws and regulations (i.e., institutions) that might otherwise impede large-scale diffusion of new technology. In the presence of this type of feedback, even better conditions are created for further improvements of the price/performance ratios.

In the recent past, we have witnessed how various policy initiatives have addressed these feedback mechanisms, with profound impacts on the global development of renewable energy technologies such as solar photovoltaic and wind power. For example, the price of PV cells has declined from more than US\$ 50/W in the mid-1970s to about US\$1-2/W today, making this technology competitive against established alternatives. ${ }^{22}$ Positive feedback between the different innovation stages allow new innovations to move from a situation in which very few actors are involved in technology development, deployment is low, and the price/performance ratio is unfavorable, to one in which new industrial sectors are created, providing a large number of jobs while at the same time powering largescale diffusion of new products.

However, the development of innovations is seldom smooth, and it can take many decades before they result in the establishment of new industries. One of the main reasons for this is that the laws and rules that prevail in a market have largely been shaped by actors with established technology, and these institutions may therefore need to be reformed before new technology can be diffused. ${ }^{23}$ One example is the electricity supply system, which historically has been dominated by large-scale power generation (e.g. nuclear energy, coal-fired power stations), but is now moving increasingly toward distributed power solutions where individuals become electricity suppliers by, for instance, installing solar panels on the roofs of their houses. Still, existing electricity regulations are largely designed for large-scale generation, and individuals with small systems may therefore find it difficult to gain access to the market.
Large-scale diffusion of new technology may therefore become possible only with institutional changes, such as the introduction of 'net charging' and/or reformed permitting processes.

\section{The different roles of industrialization and diffusion policies}

In the innovation systems literature, various types of barriers to the development and diffusion of innovations are often referred to as 'system weaknesses'; these impair the positive feedback between the various stages of the innovation process. ${ }^{12,24,25}$ If these weaknesses are not addressed, the innovation system will develop slowly. Correspondingly, 'system strengths', which instead create favorable conditions for the up-scaling of new technology, can also be identified. ${ }^{12}$ System weaknesses and strengths are often specific to various technological fields, for example different combinations of system weaknesses may have led to the stalled development of advanced biorefineries in Sweden compared to the case of biogas in Holland. ${ }^{26}$ For this reason, only introducing a general - technologyneutral - policy instrument, such as a carbon tax, will not be an effective innovation policy on its own.

From an innovation systems perspective, an important role for policymakers is to track technological fields of strategic importance, identify system strengths, stimulate positive feedback, and address system weaknesses that block further development by means of a combination of general and specific policy instruments. ${ }^{12,27}$ It also becomes important for policymakers to participate in learning processes, especially with regard to the risks associated with new technologies and the laws and regulations that need to be amended to stimulate a wider diffusion. ${ }^{28,29}$

The feedback between the various stages of the innovation process often lead to the development of further innovations following a so-called $S$-curve. New technologies have to go through four main phases of development before reaching a maturity phase. ${ }^{27}$ These phases are illustrated in Fig. 2.

The first three phases, i.e., the concept development, demonstration, and niche market phases, are essential for creating industrial capacity. Such capacity is shaped when firms and other actors learn about the new technology, when specialists are trained, and when production methods and new value chains are created, along with new habits and routines. Moreover, existing laws and regulations will often need to be amended, and new laws and regulations enacted to establish the prerequisites for large-scale diffusion of the new technology. The commercial growth phase does not follow until 


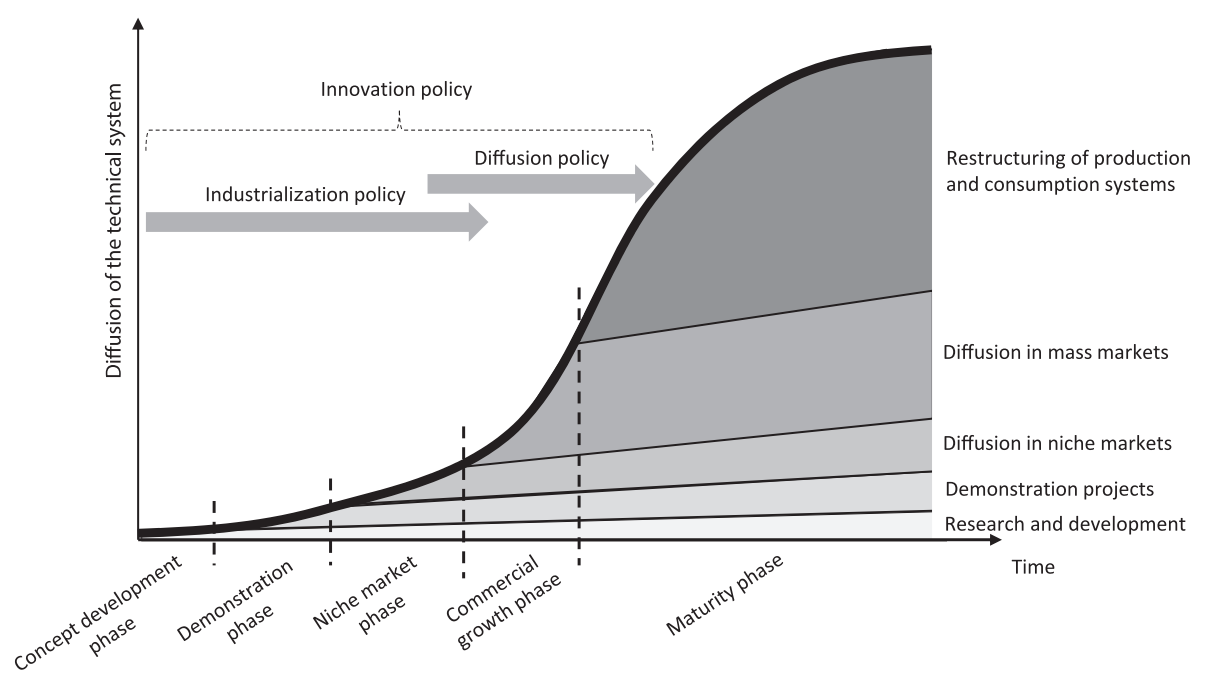

Figure 2: Diffusion of innovations through five main phases. Source: Swedish Energy Agency (2014).

the new technology has developed a favorable price/performance ratio, and the industry has the necessary capacity and opportunity for diffusing the technology on a global scale. This phase is characterized by the large-scale deployment of the new technology along with relatively fundamental social change with regard to how we use, for instance, energy and transportation services. ${ }^{\ddagger}$

When an innovation reaches the growth phase, the number of product innovations and variants of the technology usually contract. A dominant design is established, the innovations become more incremental, and the number of competing firms decline. ${ }^{30,31}$ It therefore becomes more difficult for new firms to enter and compete with established firms. An exception occurs when new firms are able to develop an entirely new product design that is superior to the old one and, in so doing, redefine the market and its conditions (e.g. the smartphone), and/or if they have cost advantages (e.g. the rise of the Chinese solar PV industry).

The innovation policy instruments needed during the first three phases are typically significantly different from the policy required in the later phases. The policy needed during the first three phases of the technological development process is here referred to as an industrialization policy; it is aimed at building up an industrial capacity and favorable conditions for further diffusion of new innovations. The policy during the two remaining phases can be

\footnotetext{
‡The advent of a new phase does not imply that the preceding phases come to an end; they proceed and often with greater vigour. For example, mature technological fields often benefit from more government-funded R\&D than do emerging areas (e.g. compare public R\&D funding for fuel combustion versus fuel cell development).
}

referred to as a diffusion policy as it is aimed at facilitating the diffusion of existing innovations, as well as opening up for incremental innovations and cost reductions.

An important role for industrialization policy is to invest in generic technologies that entrepreneurial firms then can build on, creating variations, financing R\&D and demonstration, and establishing niche markets so that the new innovations can be tested in practice. ${ }^{32,33}$ Public R\&D support and co-funding of pilot and demonstration plants, etc., are thus key policy instruments in the concept development and demonstration phases. An important component may also involve developing generic technologies, as is done in basic research institutes in Germany and in government-funded research labs in the United States.

In the niche market phase, $\mathrm{R} \& \mathrm{D}$ funding is still important but even more important is market formation. Here the products must be tested in a market with real customers, and the government will have to create the conditions for private firms to raise long-term loans (on reasonable terms) in new areas for which established financial organizations are not yet providing funds. State-owned firms and agencies can also play a role as first key customers by procuring, for example, biogas buses and new fuels. Another alternative is to enact regulations designed specifically for up-scaling.

Industrialization policies need to be technology-specific in the sense that they target pre-defined technological fields and value chains. One example is the Renewable Energy Sources Act (EEG) in Germany that has encouraged the use of new renewable energy technologies through technology-specific so-called feed-in tariffs in 
which the producers of renewable electricity sell at a preset (guaranteed) price per kWh generated over a certain time period. ${ }^{34}$ The literature describes the feed-in tariff as an effective policy instrument for stimulating innovation and forming industrial capacity for the development of wind power and PV cells, but also notes that it may not be easily adaptable to other technological fields. ${ }^{35}$

Diffusion policies are different from industrialization policies in that these should focus on creating long-term conditions that stimulate the diffusion of low-carbon technologies that already have been tested in niche markets. There are numerous policy instruments available to achieve this, such as green certificate schemes and carbon taxes. This type of policy instrument should not, in principle, discriminate between different technologies based on how mature they are, and instead focus on lowering general entry barriers for renewable energy technologies in relation to those based on fossil fuels. These policy instruments are sometimes referred to as technology neutral, although this description is somewhat misleading; all policy instruments tend to steer toward certain technologies and less toward others - in other words, they always tend to create both winners and losers. ${ }^{36}$

Naturally, a country may pursue a diffusion policy in the absence of an industrialization policy. This may however have negative consequences in that such a policy approach primarily supports the deployment of the existing solutions that are cost-effective only in the short term. Thus, the long-term development and renewal of the domestic industry may be undermined as long-term solutions with a great potential for future cost reductions are neglected. An effective diffusion policy must therefore typically be supported by an equally effective industrialization policy.

\section{Strengths and weaknesses in the innovation system for advanced bio-refineries: The case of Sweden}

The transport sector accounts for about $15 \%$ of total global greenhouse gas (GHG) emissions, and in Sweden the corresponding figure is $32 \% \cdot{ }^{27,28}$ Reducing emissions from the transport sector is therefore a prioritized area in Sweden, and a vision has been formulated stating that the country should have a fossil-independent vehicle fleet by 2030 and become one of the first fossil-free welfare countries in the world. ${ }^{37}$ Radically reducing GHG emissions from the transport sector will require heavy investments in alternative modes of transport with significantly less climate impact alongside energy efficiency improvements, increased electrification and use of biofuels. ${ }^{38,39}$ Thus, the transformation of the transport sector will involve investment in a wide variety of solutions that complement each other in various ways. ${ }^{39}$

If the processes that constitute advanced biorefineries are put into practice, they could make a substantial contribution toward realizing the government's vision of a fossilfree Sweden while at the same time creating the basis for industrial revitalization with many new potential products, services, and applications. Forestry and agriculture give rise to various by-products that could, under the right conditions, gain higher processing value. The recycling industry, the paper and pulp industry, the energy sector, the chemical industry, the oil industry, existing biorefineries and biofuel plants, etc., could play key roles since they possess the technical and organizational structures that are well-suited for integration of the technologies that make up future biorefineries.

Many of these actors have joined together in systembuilding networks and alliances, where some have been involved in developing advanced fuels and chemicals from forest resources since the 1970 s. $^{40}$ These actor networks have induced positive feedback that has in turn stimulated strong development of the biorefinery innovation system. In an empirical investigation of this innovation system, the present authors collaborated with a number of other researchers as well as with representatives from the Swedish Energy Agency, and identified nine system strengths that should be able to contribute to the creation of favorable conditions for the continued development of the technological fields. ${ }^{12,27}$

These strengths include, for instance: (i) a significant research infrastructure in the form of pilot and demonstration plants exists, which permits experimentation with alternative solutions; (ii) many value chains (e.g. ethanol, $\mathrm{DME} /$ methanol) have been tested in practice; (iii) research actors and entrepreneurial firms are linked in strong networks with international connections, have experience in the relevant technology fields, and are ready to scale up the technology; (iv) long-term R\&D funding is accessible, resulting in strong knowledge production in the fields; and (v) access to related key competencies and industrial structures in, for example, the process and chemical industry, oil industry and district heating sector, is available. ${ }^{12,15}$ Clearly, these strengths have co-evolved in complex iterative processes. For example just as the development of key competence and R\&D support have enabled the establishment of novel research infrastructure, these pilot and demonstration plants have also assisted in further building up this competence. 
In spite of significant progress, though, there has been no commercial breakthrough toward integrating the technologies that constitute advanced biorefineries into existing industrial structures. Internationally, a few commercialscale plants have been constructed, but no such plants are being built in Sweden even though several commercial projects have been proposed. Accordingly, the field is essentially positioned in a late demonstration phase while well on its way toward the niche market phase (Fig. 3). Still, for this to happen, one or more of the novel technologies must be up-scaled to commercial size and in this way generate learning, both via feedback from customers and users (learning-by-using) and through increased production volumes (learning-by-doing).

Thus, in order for the field to reach the commercial growth phase, the Swedish government needs to - in a first step - pursue an industrialization policy wherein a number of technical concepts are tested on a commercial scale. A realistic target for the overall policy initiatives could be around 20 TWh of green fuels and chemicals by the year 2030, in turn corresponding to the construction of about 8-12 plants on a commercial scale. ${ }^{12,27}$ While this would be a significant achievement from a national perspective, it is still relatively modest when viewed from a global perspective. Still, since innovation processes are genuinely uncertain, we cannot know for sure whether such an initiative would suffice for the field to reach a commercial growth phase; thereby resulting in a larger scale diffusion also to other contexts without additional, very specific, deployment instruments.

In our previous research, we also highlight seven system weaknesses that would have to be addressed for the biorefinery field to have any chance of reaching a growth phase by 2030 . These are outlined in Table 1, and then elaborated on in the remainder of this section. ${ }^{12,27}$

To shift the field from the demonstration to the niche market phase, new types of policy instruments will be required and additional policy actors will need to step in to stimulate the development. This is because various government ministries and agencies have control over various types of policy instruments. Knowledge of emerging technological fields also varies across agencies and ministries, which therefore need to coordinate their efforts and identify policy instruments suitable for the niche market phase (Weakness \#1 in Table 1).

At present, there are no policy instruments for the niche market phase and there are no naturally occurring niche markets for biofuels that can justify investments in commercial-scale advanced biorefineries (Weakness \#2). This is the case in Sweden as well as in many other forest-rich countries, such as the USA and Canada. ${ }^{10}$ For this reason

\section{Table 1. System weaknesses in the Swedish} innovation system for biorefineries.

System weaknesses

\#1: Weak coordination among government ministries, agencies, and regional actors.

\#2: Insufficient policy instruments in the niche market phase.

\#3: Insufficient policy instruments in a growth phase.

\#4: Weak industrial participation and industrial absorptive capacity.

\#5: Weak cooperation across knowledge and organizational boundaries.

\#6: Vague roles, collaboration, ownership, and financing of the research infrastructure.

\#7: Competition from fossil resources and alternative uses of biomass.

Sources: Swedish Energy Agency (2014) and Hellsmark et. al. $(2016)^{12,13}$

there exists a time gap between the demonstration and niche market phases, in that commercial actors are ready to scale up the technology but the necessary prerequisites are not present. As a consequence, key competencies in the field can be lost and the large and more established actors may choose to invest in other areas (Weaknesses \#1 and 2).

In Sweden there is also a lack of long-term policy instruments for fuels in a growth phase (Weakness \#3). ${ }^{14}$ At present, biofuels benefit from a reduced carbon tax, which makes the already established alternatives (e.g. HVO, biodiesel, and ethanol) profitable compared to the use of fossil fuels. This tax exemption is, however, renewed every year, and the European Commission has extended approval of this state aid throughout 2017. Until a more long-term stable system is in place, no new investments are likely to emerge in either established or new technologies that depend on this tax exemption.

The realization of advanced biorefineries is also dependent on mature industries, such as the chemical industry, forest industry, oil industry, and/or the district heating sector, choosing to integrate radically new technology into their existing operations and establish partnerships with other organizations that have completely different knowledge bases. This would involve a relatively radical transition for firms and industries that for long have specialized in a certain number of products and markets by establishing long-lived cooperation with suppliers and customers. Such specialization has reinforced their capacity to compete in international markets, but it has also weakened the conditions for taking part in long-term R\&D projects and being 
actively involved in developing products and processes in entirely different areas (e.g. green fuels, chemicals).

For these firms to take an active part in the transformation, action needs to be taken to strengthen their capacity to assimilate new knowledge that lies outside their existing competencies and business areas (an ability often referred to as absorptive capacity) (Weakness \#4). One important measure could be to actively support partnerships between firms and organizations with complementary expertise (Weakness \#5), so that new technological solutions can be deployed in practice and new value chains established. For instance, participation of both the forest industries and catalyst providers is necessary to further biorefinery development, but these actors have been difficult to engage in the networks surrounding the major pilot and demonstration plants in Sweden. Biorefineries build on large investments in mature industries and the policy instruments designed to encourage such investments must also be longterm and provide a reasonable profit margin. Otherwise, firms have alternative investments to make that can provide high returns and are not dependent on state aid. These alternatives, however, do not lead to increased production of renewable fuels and chemicals (Weakness \#7).

\section{Policy instrument choice for technology up-scaling and diffusion}

In this section we argue that an entire portfolio of different policy instruments needs to be reviewed and implemented to stimulate technological development and diffusion in the biorefinery field, and in this way strengthen industrial competitiveness and attain fossil-fuel independence. This portfolio needs to be composed of policy instruments aimed at both the niche market phase and the growth phase. In addition, the type of policy instruments that are most appropriate in the niche market phase depends on the policy instrument in effect during the growth phase and vis à vis. Accordingly, we discuss policy instruments in the growth phase first, and then return to the issue of policy instrument choice for technologies in the niche market phase. Figure 3

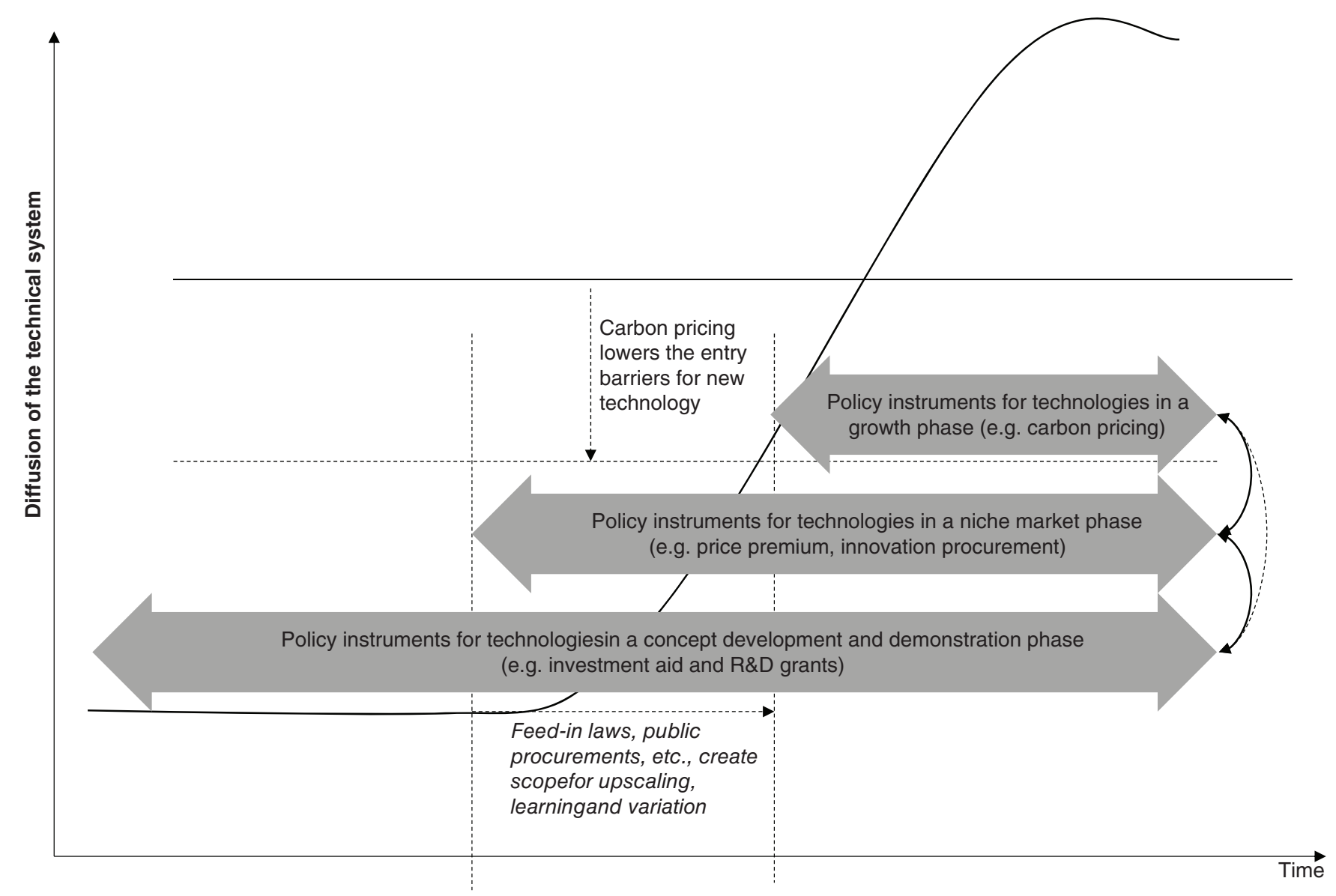

Figure 3: The combination of policy instruments and how they are implemented is the key to a successful innovation policy. 
summarizes our assessment of the role of different policy mixes in progressing advanced biorefinery technology.

\section{Policy instruments for technologies in the growth phase}

Various national systems of carbon pricing have been used to stimulate the use of renewable fuels in the transport sector. For instance, Sweden has had energy and carbon tax exemptions for fuels based on renewable resources, and Finland has recently implemented a carbon surcharge on all fuels based on the carbon content of the fuels. Germany has implemented a carbon ceiling for the transport sector that is continuously lowered, also taking the relative climate performance of various fuels into account. For carbon pricing to stimulate the diffusion of new technology, the most important factors are that the price is high enough, that the system is long-term, and that the carbon price is raised over time to account for a tighter carbon budget. In addition, there should be differentiation between types of fuels based on their actual emissions. Carbon pricing can thus lower the entry barriers for renewable alternatives vis-à-vis fossil fuels and promote a clear differentiation across fuels based on climate performance.

An alternative to carbon pricing could be a mandatory quota system. This has been heavily discussed in Sweden and is already used in a number of EU countries. ${ }^{41}$ Such quotas typically involve an obligation for retailers to purchase a pre-determined amount (or share) of renewable fuels (e.g. in MWh). The advantage of a mandatory quota is that it creates a protected space for renewable fuels where they do not have to compete with fossil alternatives.

Quotas can be an effective policy instrument for diffusing relatively mature technologies that are in a growth phase and in cases where there is a good understanding of the opportunities for up-scaling. If these conditions are not met, it will be difficult to determine an appropriate target level. Mandatory quotas are typically designed in a technology-neutral manner, thus creating competition between various renewable alternatives. In this way they tend to favor established actors with existing production, distribution systems, and end-use markets, and that relatively easily can increase their production without major new investments. ${ }^{35,42}$

Products that are cost-effective in the short-term tend to be favored over less-developed products but with a significant long-run development potential. Low-level blends also tend to be favored over pure biofuels like E85, ED95, and biogas. Previous research confirms that quota schemes have tended to be less innovation-promoting compared to, for instance, fixed feed-in tariff schemes. ${ }^{35}$ This means that the entry barriers may not necessarily be lowered for the less mature but perhaps more promising technologies; instead a separate market is created to diffuse technologies in a growth phase. This also illustrates the need to implement separate policy instruments in the niche market phase.

\section{Policy instruments for technologies in a niche market phase}

Neither mandatory quotas nor carbon pricing are sufficient instruments for stimulating investment in advanced biorefineries, and thus for assisting in creating the necessary industrial capacity in this field. Most notably, carbon pricing does not provide enough incentives for investments in the first commercial-scale plants. The production costs in these plants must be lowered through a number of learning processes (i.e., learning-by-doing and learning-by-using) before the new technology can compete with the established alternatives (both renewables and fossil fuels). Policy instruments in the niche market phase need to build on the understanding that developing the advanced biorefinery field is likely to be a lengthy and highly uncertain process where very few (if any) existing or new actors will be willing to assume initial investment risks. In addition, venture capitalists seldom fill the funding void for new innovations in the early stages, and particularly in knowledge-based sectors in which capital intensities and the technological complexity are high.

In practice, this means that the policy instruments in the niche market phase need to create stable conditions for individual investments over a long period of time. In various ways, they should therefore resemble the feed-in tariff policies used to promote industrial development, learning, and diffusion of, for example, wind power and solar PV in Germany, through stimulating investments in the first plants. Innovation is nurtured through targeted support of protected technological niches. A mandatory quota for advanced biofuels would probably not be able to achieve this effectively; with such a quota investors do not know what price they can expect and whether it will be high enough to compensate for the immaturity of the technology. As noted earlier, most existing quota schemes stimulate direct competition between different fuels, thus primarily favoring technologies with the highest shortterm potential. ${ }^{35,42}$ 
A price premium model that provides a price guarantee (above the market price) to producers could be a feasible route in a niche market phase. ${ }^{43}$ Another policy alternative that has not been analyzed much from an innovation system perspective is the public procurement of biofuels and biobased chemicals. Here public actors in dialogue with technology developers form a partnership to purchase fuels or chemicals according to certain specifications concerning type, environmental performance, basic resources, and technical maturity at a fixed price during a predefined time period (e.g. $10-15$ years). Similar to a feed-in tariff, such a policy could provide a temporary protected space in which the technology can develop with less direct competition from other alternatives. This instrument would, however, also need to be combined with carbon pricing to stimulate wider diffusion.

Regardless of which policy instrument is chosen, the design and implementation of the instrument is at least as important as choosing the right category. In the niche market phase, long-term stability is of utmost importance. Moreover, it is also important that the goal of the policy instrument is made clear from the outset, which firms will be affected, and whether the policy provides clear support so that the relevant firms will be able to make the necessary investments, by raising bank loans, etc.

\section{Conclusion}

The overall aim of this paper was to provide a perspective on the type of innovation policy mixes required to realize advanced biorefineries with a focus on biofuel production. Corresponding arguments apply to bio-based chemicals, other than that the markets and firms may differ and that the market is not as politically controlled through taxation as in the case of transport fuels. There should, however, be clear synergies in biorefineries between concurrent production of biofuels, bio-based chemicals, and bio-energy, where the realization of one area ought to improve the conditions for the other areas.

The key message of the paper is that progressing the field of advanced biorefineries requires an industrialization policy that can create a market for renewable fuels and green chemicals, thus supporting technology development during a niche market phase and allowing for the first commercial-scale plants to be built. The purpose of such a policy is to stimulate learning, form value chains, and experiment with various design options on a larger scale. It would also facilitate incremental innovations that allow key technologies to progress down the learning curve to eventually become competitive. Policy instrument candidates for the niche market phase include, for example, public procurement and various types of price guarantees, perhaps combined with investment subsidies.

If the Swedish government wishes to strengthen the competitiveness of the country's industrial sectors by taking the lead in developing the 'climate-smart innovations the world is asking for', the formulation of effective innovation policies must emanate from a strong political leadership that follows through on all levels between R\&D and market diffusion. Other countries in, for instance, Europe and North America, experience similar challenges as Sweden with respect to the development of advanced biorefineries, such as a lack of niche markets. For this reason, our case study, and the key implications outlined, should be of interest well beyond the Swedish market and could help policymakers and other actors in international markets to capitalize on strengths, eliminate weaknesses, and propose new policy mixes for developing the biorefinery innovation system.

\section{Acknowledgements}

We gratefully acknowledge financial support for the present study from the Swedish Research Council Formas and $\mathrm{f} 3$. We have also received useful comments when the idea for the paper was discussed during a workshop with representatives of the forest industry, the chemical industry, and other researchers in the field. Comments from Professor Staffan Jacobsson and two anonymous reviewers on an earlier draft of the paper have been very useful and highly appreciated. Any remaining errors, though, reside solely with the authors.

\section{References}

1. Rogelj J, Luderer G, Pietzcker RC, Kriegler E, Schaeffer M, Krey $\mathrm{V}$ et al., Energy system transformations for limiting endof-century warming to below 1.5 [deg]C. Nat Clim Chang 5(6):519-527 (2015).

2. Grubler A, Technology and Global Change. Cambridge University Press, Cambridge (1998).

3. Wilson C, Up-scaling, formative phases, and learning in the historical diffusion of energy technologies. Energy Policy 50:81-94 (2012).

4. IEA, Biorefineries: adding value to the sustainable utilisation of biomass. IEA Bioenergy, task 42, Paris, 2009:01 (2009).

5. de Besi M and McCormick K, Towards a bioeconomy in Europe: National, regional and industrial strategies. Sustainability 7(8):10461-10478 (2015).

6. Staffas L, Gustavsson M and McCormick K, Strategies and policies for the bioeconomy and bio-based economy: An analysis of official national approaches. Sustainability 5(6):27512769 (2013).

7. Iles A and Martin AN, Expanding bioplastics production: Sustainable business innovation in the chemical industry. $J$ Clean Prod 45:38-49 (2013). 
8. Kleinschmit D, Lindstad BH, Thorsen BJ, Toppinen A, Roos A and Baardsen S, Shades of green: A social scientific view on bioeconomy in the forest sector. Scand J For Res 7581:1-31 (2014).

9. Pandey A, Larroche C, Ricke S, Dussap C-G and Gnansounou E, Biofuels: Alternative Feedstocks and Conversion Processes. Elsevier Inc., Oxford, UK (2011).

10. Huenteler J, Anadon LD, Lee H and Santen N, Commercializing second-generation biofuels. Scaling up sustainable supply chains and the role of public policy. Belfer Center for Science and International Affairs, Harvard University, Cambridge, USA (2014).

11. Bacovsky D, Overview of advanced biofuels technologies. European Biofuels Technology Platform 6th Stakeholder Plenary Meeting SPM6: Biofuels for Low Carbon Transport \& Energy Security, 14-15 October 2014, Diamant Conference Centre, Brussels (2014).

12. Hellsmark H, Mossberg J, Söderholm P and Frishammar J, Innovation system strengths and weaknesses in progressing sustainable technology: the case of Swedish biorefinery development. J Clean Prod 131:702-715 (2016).

13. UN Sustainability Summit. [Online]. New York, 26 September 2015. Available: http://www.government.se/ speeches/2015/09/speech-at-the-un-sustainable-develop ment-summit/ [accessed October 19, 2016].

14. Swedish Energy Agency, Energy in Sweden, facts and figures 2014. Swedish Energy Agency, Eskilstuna (2014).

15. Grahn $M$ and Hansson J, Prospects for domestic biofuels for transport in Sweden 2030 based on current production and future plans. Wiley Interdiscip Rev Energy Environ 4(3):290-306 (2015).

16. Schumpeter JA, The Theory of Economic Development. Harvard University Press, Cambridge, MA, USA (1934).

17. Kline SJ and Rosenberg N, An overview of innovation, in The Positive Sum Strategy Harnessing Technology for Economic Growth, ed by Landau R and Rosenberg N. National Academy, Washington, DC, pp. 275-306 (1986).

18. Foray D, The New Economics of Technology Policy. Edward Elgar, Cheltenham, UK (2009).

19. Thompson P, Chapter 10 - Learning by Doing, in Handbook of the Economics of Innovation, ed by Hall BH \& Rosenberg and publisher: North Holland, Amsterdam (2010).

20. Rosenberg N, Inside the Black Box: Technology and Economics. Cambridge University Press, Cambridge (1983).

21. Lundvall B-Å and Johnson B. The learning economy. J Ind Stud 1(2):23-42 (1994).

22. IPCC, Special Report on Renewable Energy Sources and Climate Change Mitigation. Prepared by Working Group III of the Intergovernmental Panel on Climate Change. University Press, Cambridge, United Kingdom and New York (2011).

23. Hughes TP, The evolution of large technological systems, in The Social Construction of Technological Systems, ed by Bijker WE, Huges TP and Pinch T. MIT Press, Cambridge, MA, USA, pp. 51-82 (1987).

24. Wieczorek $A$ and Hekkert M, Systemic instruments for systemic innovation problems: A framework for policy makers and innovation scholars. Sci Public Policy 39:74-87 (2012).

25. Bergek A, Jacobsson S, Carlsson B, Lindmark S and Rickne A, Analyzing the functional dynamics of technological innovation systems: A scheme of analysis. Res Policy 37(3):407-429 (2008).

26. Negro SO, Suurs RAA and Hekkert MP, The bumpy road of biomass gasification in the Netherlands: Explaining the rise and fall of an emerging innovation system. Technol Forecast Soc Change 75(1):57-77 (2008).

27. Swedish Energy Agency, Teknologiska innovationssystem inom energiområdet: En praktisk vägledning till identifiering av systemsvagheter som motiverar särskilda politiska åtaganden, ER 2014:23. Swedish Energy Agency, Eskilstuna (2014).

28. Dalum B, Johnson B and Lundvall B-Å, Public policy the learning society, in National Systems of Innovation: Towards a Theory of Innovation and Interactive Learning, ed by BengtÅke L. Pinter, London (1992).

29. Lundvall B-Å, National Systems of Innovation: Towards a Theory of Innovation and Interactive Learning. Pinter, London (1992).

30. Tushman $\mathrm{ML}$ and Anderson $\mathrm{P}$, Technological discontinuities and organizational environments. Adm Sci Q 31(3):439-465 (1986).

31. Abernathy WJ and Utterback JM, Patterns of industrial innovation. Technol Rev 80(7):40-47 (1978).

32. Mazzucato M, The Entrepreneurial State - Debunking Public vs. Private Sector Myths. Anthem Press, New York, USA (2013).

33. Kemp R, Schot J and Hoogma R, Regime shifts to sustainability through processes of niche formation: The approach of strategic niche management. Technol Anal Strateg Manag 10(2):175-196 (1998).

34. Gawel E, Lehmann P, Purkus A, Söderholm P and Witte K, The Rationales for Technology-Specific Renewable Energy Support: Conceptual Arguments and their Relevance for Germany. UFZ Discussion Paper 4/2016. Helmholtz Centre for Environmental Research - UFZ, Leipzig, Germany (2016).

35. del Río P and Bleda, Comparing the innovation effects of support schemes for renewable electricity technologies: A function of innovation approach. Energy Policy 50:272-282 (2012).

36. Sandén BA and Azar C, Near-term technology policies for longterm climate targets--economy wide versus technology specific approaches. Energy Policy 33(12):1557-1576 (2005).

37. Riksdagen, Regeringens proposition 2008/09: 163, En sammanhållen klimat- och energipolitik: Energi. Riksdagen, Stockholm (2008).

38. IEA, Technology Roadmap Biofuels for Transport. IEA (International Energy Agency), Paris (2011).

39. Johansson TB, Fossilfrihet på väg: Betänkande av Utredningen om fossilfri fordonstrafik SOU, Miljö- och energidepartementet, Stockholm 2013:84 (2013).

40. Hellsmark H, Frishammar J, Söderholm P, Ylinenpää $H$, The role of pilot and demonstration plants in technology development and innovation policy. Res Policy 45(9):1743-1761 (2016).

41. Grönkvist S, Peck P, Silveira S, Åkerman J, Larsson M and Khedkar P, Policy Instruments Directed at Renewable Transportation Fuels - An International Comparison. Report No. 2013:15. The Swedish Knowledge Centre for Renewable Transportation Fuels (f3), Göteborg, Sweden (2013). Available at: www.f3centre.se

42. Bergek $A$ and Jacobsson $S$, Are tradable green certificates a cost-efficient policy driving technical change or a rent-generating machine? Lessons from Sweden 2003-2008. Energy Policy 38(3):1255-1271 (2010).

43. Kåberger T, Underlagsrapport 24 - Stöd till inhemsk produktion av andra generationens biodrivmedel. SOU N 2012:05 Utredningen om fossiloberoende fordonsflotta, Statens Offentliga Utredningar, Miljö- och energidepartementet, Stockholm (2013). 


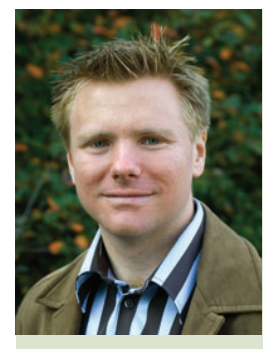

\section{Hans Hellsmark}

Hans Hellsmark is a researcher at Chalmers University of Technology and coordinator of the Chalmers Initiative for Innovation and Sustainability Transitions. His research focus is on innovation policy related to societal transition processes in general and the transition to a bio-economy in particular.

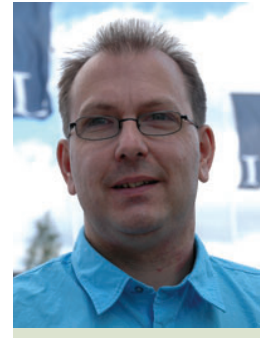

\section{Patrik Söderholm}

Patrik Söderholm is Professor of Economics at Luleå University of Technology, Sweden. His research focuses on energy and forest raw materials markets, and the efficiency of environmental, energy, and climate policy instruments. This includes a lot of work on technology learning and innovation. 